\title{
SPRAWOZDANIE Z KONFERENCJI „SEX OR GENDER W POSZUKIWANIU NATURY I KULTURY". TORUŃ, 24 MAJA 2012 ROKU
}

W dniu 24 maja 2012 roku odbyła się ogólnopolska konferencja "Sex or gender w poszukiwaniu natury i kultury" zorganizowana przez Zakład Pedagogiki Pastoralnej Wydziału Teologicznego Uniwersytetu Mikołaja Kopernika w Toruniu.

Na początku zgromadzonych przywitał ks. prof. dr hab. Jan Perszon, dziekan Wydziału Teologicznego, który życzył wszystkim słuchaczom egzystencjalnych przeżyć. Jako następny wynikami badań, które przeprowadził razem ze studentami III roku nauk o rodzinie, podzielił się ks. dr hab. Wojciech Cichosz, prof. WSKS. Dotyczyły one płci biologicznej i kulturowej i zostały przeprowadzone na populacji 369 studentów, którzy odpowiadali na pytania mające wskazać, czy i jak pojęcie "gender" jest rozumiane przez studentów UMK.

Pierwszym, który wygłosił swój referat na temat „Mężczyzną i niewiastą stworzył ich (Rdz 1,17)", był ks. dr hab. Grzegorz Szamocki, prof. UG, który ukazał starotestamentową perspektywę tego, co nazywa-

* Karolina Olszewska - studentka IV roku teologii na Wydziale Teologicznym UMK w Toruniu. Działa w Kole Młodych Teologów. 
my „zróżnicowaniem płciowym”. Aby poszerzyć kontekst historyczny omawianego zagadnienia, prelegent nawiązał do literatury pozabiblijnej, np. do Uczty Platona, w której Arystofanes opisywał człowieka jako byt złożony z dwóch połówek, które po rozdzieleniu wzajemnie się przyciągają. I to wzajemne przyciąganie można nazwać miłością. W mitologii greckiej odmienność płciowa była karą boską. Również w Talmudzie i Kabale pierwszy człowiek był hermafrodytą. Ksiądz profesor przedstawił twierdzenie rabbiego Jeremiasza, który wyznawał pogląd, że Adam miał dwie twarze, jedną z tyłu, drugą z przodu, i ta przednia twarz należała do mężczyzny. Na potwierdzenie tej tezy mogą służyć słowa rabbiego Eleazara, który stwierdził, że mężczyzna bez kobiety nie jest człowiekiem. Komentując fragment $\operatorname{Rdz} 1$,27, rektor seminarium gdańskiego przedstawił tezę, że obraz Boga w człowieku nie jest kompletny dopóki, dopóty mężczyzna i kobieta nie są w akcie prokreacji. Ksiądz Szamocki ukazał także alegoryczne spojrzenie ojców Kościoła na ten fragment. Orygenes stwierdził, że w omawianym fragmencie typem męskim jest Chrystus, natomiast typem żeńskim - Kościół. Grzegorz z Nysy natomiast uważał, że w tym wersecie dodatek „stworzył mężczyznę i niewiastę" jest późniejszy, z czego można wyprowadzić wniosek, że na początku swojego istnienia człowiek był bezpłciowy. W dalszej części referatu prelegent przeszedł do krytyki tekstu, stwierdzając, że wspomniany fragment pochodzi z tradycji kapłańskiej i jest pierwotniejszy niż fragment o stworzeniu świata. Użyte w tekście oryginalnym słowo „podobieństwo” jest w apozycji do słowa „obraz”. Po raz kolejny wyraz „podobieństwo” można spotkać w Rdz 5, gdzie czytamy, że Adam miał syna na swoje podobieństwo. Występuje tutaj hendiadys, czyli figura retoryczna, w której za pomocą dwóch słów jest wyrażona jakaś idea. W tym przypadku chodzi o podkreślenie faktu, że coś z ojca znajduje się w synu, coś się może między nimi dokonywać. Rektor gdańskiego seminarium podkreślił fakt, że Bóg jest kreatorem, natomiast człowiek tylko, lub aż, prokreatorem, oraz stwierdził, że ludzkie podobieństwo obejmuje płciowość, dlatego aby je przekazać, potrzeba kobiety i mężczyzny. W związku $\mathrm{z}$ tym promowanym w Biblii modelem związku jest heteroseksualizm, który zawiera w sobie wątek prokreacji. To para heteroseksualna została pobłogosławiona przez Boga, a prokreacja była niezbędna, aby wykonać nakaz edeński - ujarzmić ziemię i zwierzęta. We wnioskach prelegent stwierdził, że istotą omawianego fragmentu jest genealogiczna transmisja Bożego podobieństwa, relacja do Boga powinna bowiem być przekazywana. 
Kolejny referat wygłosił ks. dr hab. Dariusz Kotecki, prof. UMK, na temat "Mężczyzną i niewiastą stworzył ich. Perspektywa nowotestamentowa". Prelegent rozpoczął od zdefiniowania pojęcia "gender" i podkreślenia faktu, że w dzisiejszym świecie nie mówi się już o mężczyźnie i kobiecie, ale o męskości i kobiecości. Odzwierciedlenie inności płciowej jest podkreślone przez Jezusa, który powołuje się na Księgę Rodzaju, wygłaszając swoje pouczenia dotyczące małżeństwa. Różnica gatunku była podkreślona już w akcie stworzenia, jednak zróżnicowanie płciowe zakłada podobieństwo natury. W dalszej części swojego wystąpienia ksiądz profesor powoływał się na naukę zawartą w pismach pawłowych. W 1 Kor 7 Apostoł stwierdza, że rzeczą dobrą jest nie dotykać kobiety - wskazany mamy tutaj aspekt związku kobiety i mężczyzny lub seksualności. Tak radykalne stwierdzenie może być odzwierciedleniem poglądów ascetów, których nie brakowało w gminie korynckiej. Św. Paweł uważa, że małżeństwo chroni przed rozpustą, a oddawanie wzajemnej powinności wskazuje na kontrakt, w którym zawarte jest współżycie. Chiastyczny układ w 1 Kor 7,3-4 podkreśla równość między mężem a żoną. Jeśli małżonkowie są gotowi, aby podjąć się wstrzemięźliwości małżeńskiej, są zobowiązani do spełnienia trzech warunków, mianowicie akt ten wymaga: obopólnej zgody, czasowości oraz oddania się modlitwie. W kolejnym punkcie referatu ks. Kotecki zajął się problemem homoseksualizmu w listach św. Pawła. Według Rz 1,26-27 homoseksualizm świadczy o bezbożności kobiety i mężczyzny, jest to problem wykraczający poza płeć. W 1 Kor 6,9-10 Apostoł wymienia postępowania niekonwencjonalne, które wykluczają z posiadania dziedzictwa w królestwie Bożym, wśród tych uczynków jest również homoseksualizm. Jednak warto podkreślić, że Paweł nie jest „homofobem”. Negacja homoseksualizmu bierze się z użycia przez Apostoła Narodów tych samych pojęć co w Rdz 1,27 w LXX, mianowicie: qÁluj - kobieta i Ąrshn - mężczyzna, te terminy określają bowiem komplementarność tych dwóch płci, a każde wykroczenie poza ten związek jest niegodne. W listach pawłowych nie ma także idei podporządkowania płci, ponieważ wszystko pochodzi od Boga, natomiast mężczyzna rodzi się z kobiety, a kobieta pochodzi z mężczyzny. Św. Paweł podkreśla też fakt, że w Chrystusie mężczyzna i kobieta są kimś jednym, co mogłoby zaprzeczać całej idei zawartej w Rdz, gdyż Apostoł stosuje negację religijną, cywilną, a nawet seksualną. Chrystus również daje do zrozumienia, że po zmartwychwstaniu będziemy funkcjonować w niebie jak anioły. Paweł mówi o żyjących już teraz, już teraz mamy bowiem udział w Chrystusie, jednak nie jest to negacja biologiczna. We 
wnioskach prelegent stwierdził, że Nowy Testament zakłada zróżnicowanie płciowe, ze względów teologicznych - tak Bóg stworzył ludzi oraz mając na uwadze porządek natury. Mimo prób wprowadzenia zmian do prawa Bożego nic nie jest $\mathrm{w}$ stanie go poprawić.

Referat na temat „Płeć mózgu” wygłosił pan prof. dr hab. Aleksander Araszkiewicz, kierownik Katedry Psychiatrii Wydziału Lekarskiego UMK. Na początku prelegent stwierdził, że mężczyzna i kobieta różnią się od siebie nie tylko fizycznie, ale także strukturalnie. Różnica ta sprowadza się do różnicy w mózgu. Lewa półkula mózgu odpowiadająca między innymi za przetwarzanie informacji i logikę jest lepiej rozwinięta u mężczyzny, natomiast prawa, odpowiadająca za myślenie abstrakcyjne i reakcje emocjami - u kobiety. Kobiety mają większy odsetek istoty szarej niż mężczyźni, mężczyźni natomiast mają bardziej asymetryczny mózg niż kobiety. Umysł kobiety jest lepszy niż męski w tym, że pracuje cały. Kobiety i mężczyźni mają różne sposoby na rozwiązywanie problemów, co również świadczy o ich zróżnicowaniu strukturalnym. W dalszej części referatu pan profesor ukazał wpływ hormonów płciowych na mózg. Do 8 tygodnia ciąży mózg płodu jest bardziej kobiecy, później pod wpływem testosteronu (w przypadku chłopca) dochodzi do zmian. Hormony regulują także niektóre zachowania: mężczyźni są bardzie agresywni, natomiast kobiety cechuje większa tkliwość i empatia. Również zachowania seksualne są zróżnicowane ze względu na płeć. Mężczyźni myślą o stosunku płciowym średnio 10-20 razy dziennie, natomiast orgazm kobiety oprócz aspektu przyjemności zawiera też nastawienie na prokreację. Intensywny orgazm warunkuje zasysanie plemników, dlatego dla kobiety nawet aktywność seksualna ma na celu zachowanie gatunku. We wnioskach prelegent stwierdził, że biologia ma prymat nad mózgiem, jeśli chodzi o zróżnicowanie płci, jednak nie można wykluczyć działania mózgu w tej kwestii.

Kolejnym prelegentem był pan prof. dr hab. Marian Grabowski, kierownik Zakładu Filozofii Chrześcijańskiej WT UMK, który wygłosił referat na temat „Filozofia miłości Karola Wojtyły”. Na początku swojego wystąpienia prelegent wprowadził rozróżnienie między seksualnością a miłością seksualną. Przedstawił także wojtyliańskie równanie człowieka, w myśl którego człowiek to istota seksualna + osoba. Osoba miłuje, tzn. oddaje siebie drugiej osobie, natomiast istota seksualna używa. W kolejnym punkcie referatu pan profesor przeprowadził słuchaczy przez pojęcie miłości oblubieńczej, której podstawą ontyczną jest oddawanie swojego „ja", siebie, a nie tego, co moje. Wydawać by się mogło, że miłość oblu- 
bieńcza jest nie do obrony w przypadku rozważania jej w małżeństwie, w każdym człowieku dochodzi bowiem do głosu egoizm zmysłów, samolubność uczuć oraz chęć brania nad dawanie. Jednak jeśli wprowadzimy pojęcie oblubieńczego sensu ciała, niewinnej seksualności, nieprzenikniętej przez grzech, „nadążania” za wartością osoby, „dociągania” każdej wartości do relacji "ciała” i „płci”, to teza o miłości oblubieńczej w małżeństwie będzie do utrzymania. Kolejny aspekt poruszony przez pana profesora to nieczystość ludzkiego wnętrza, stojąca w opozycji do czystości, która stoi na straży miłości. Na końcu prelegent przedstawił „morał”, w którym zawarł myśl, że istnieje miłość, która nie sprowadza się ani do "sex”, ani do "gender". Zaproponował on także ewolucję tematu z "Sex or gender" na „Sex or gender?”, a dalej „Neither sex or nor gender but Sexual love”.

Jako ostatnia referat na temat "Gender, performatywność, queer... Płeć i seksualność w perspektywie kulturowej” przedstawiła pani dr hab. Lucyna Kopcewicz, prof. UG. Podkreśliła ona fakt, że feminizm to akcentowanie różnic, a nie dążenie do ujednolicenia. Na początku swojego wystąpienia pani profesor przedstawiła pokrótce historię feminizmu, wyprowadzając ją od XIX wieku i wejścia kobiet jako matek do sfery publicznej, następnie omówiła zaangażowanie kobiet $\mathrm{w}$ walkę $\mathrm{z}$ niewolnictwem. Pani prelegent zwróciła także uwagę na wielki stopień samoorganizacji kobiet, które chcąc zmienić świat, rozpoczynają od zmiany siebie. Następnie pani profesor przeszła do omawiania zagadnienia "queeru”, czyli kwestii gejowskiej wywodzącej się z socjologii przestępczości, dokładnie dewiacji. Homoseksualista uważany był za chorego, za człowieka, który uległ dewiacji. W latach 60. społeczność homoseksualna zaczyna budować swój model. W roku 1968 w jednym z miast w USA nastąpił nalot na klub gejowski, ponieważ homoseksualistów uważało się wtedy za zniewieściałych chłopców, co jednak doprowadziło do kilkudniowych walk gejów z policja, w wyniku czego powstała pierwsza organizacja gejowska. W opinii społecznej tamtych czasów pojawiło się przekonanie, że AIDS, który tak często dotykał homoseksualnych mężczyzn, jest karą za grzech sodomii. Od lat 90. mniejszości seksualne zaczęły domagać się praw do uznania ich związków i małżeństw. Kolejnym zagadnieniem poruszonym przez panią prelegent była „performatywność”, czyli polityka braku tożsamości. Do ogólnie przyjętych norm powoli można zaliczyć chłopca, który publicznie bawi się lalkami, co jeszcze kilkadziesiąt lat temu było nie do pomyślenia. Pojęciu performatywności można również przypisać aspekt magii, ponieważ nadanie komuś lub czemuś jakiejś nazwy niesie za sobą przypisanie tej osobie lub rzeczy konkretnej mocy. 
Po ostatnim referacie odbyła się dyskusja, której moderatorem był pan dr Krzysztof Pilarz. Rozpoczął on od zadania pytania, czy ci, którzy przynależą do "queeru”, są nieczyści w budowaniu swojej tożsamości. Pan prof. Grabowski odpowiedział, że tożsamość kulturowa powinna dać dojść do głosu tożsamości stworzonej przez Boga, oraz zauważył, że pojęciowanie dotyczące szeroko rozumianej definicji "genderu" jest jeszcze bardzo prymitywne, co pani prof. Kopcewicz zripostowała, twierdząc, że język, który miałby opisywać wspomniane wyżej pojęcie, nie jest jeszcze prymitywny, ale nie można na pewno nazwać go prymitywnym. W dalszym toku dyskusji pani profesor zwróciła również uwagę na fakt, że w społeczeństwie szwedzkim czy francuskim polityka emancypacyjna jest równa "genderyzmowi", jednak ks. prof. Kotecki zauważył, że w tych społeczeństwach decydującą rolę odgrywa polityka ekonomiczna państwa wobec kobiet i rodziny.

Konferencja poświęcona płci biologicznej i kulturowej pokazała, jak może wyglądać debata akademicka, w której udział wzięli przedstawiciele różnych nauk. Może stać się ona przyczynkiem do poszerzenia badań nad "genderyzmem", zdefiniowania zagrożenia bądź dobra, jakie niesie ze sobą ten nurt, a także przedstawienia go od strony czysto teoretycznej i stworzenia nowego słownika pojęć. Referaty oraz wnioski, które zostały wygłoszone podczas tej sesji naukowej, zostaną zawarte w publikacji pokonferencyjnej. 